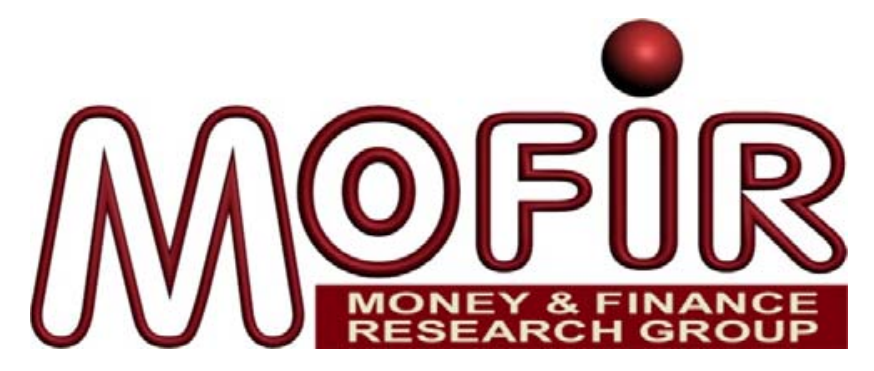

\title{
WERE MULTINATIONAL BANKS TAKING EXCESSIVE RISKS BEFORE THE RECENT FINANCIAL CRISIS?
}

MOHAMED AZZIM GULAMHUSSEN

University Institute of Lisbon

CARLOS PINHEIRO

Caiza Geral de Depositos

AlBeRTo FrANCO POZZOLO

Università degli Studi del Molise

MoFiR working paper $n^{\circ} 69$

May 2012 



\title{
Were multinational banks taking excessive risks before the recent financial crisis?
}

\author{
Mohamed Azzim Gulamhussen \\ (University Institute of Lisbon) \\ Carlos Pinheiro \\ (Caixa Geral de Depósitos)
}

Alberto Franco Pozzolo**

(Università degli Studi del Molise, MoFiR, CASMeF and Centro Studi Luca D’Agliano)

\begin{abstract}
$\underline{\text { Abstract }}$
The recent financial crisis has clearly shown that the relationship between bank internationalization and risk is complex. Multinational banks can benefit from portfolio diversification, reducing their overall riskiness, but this effect can be offset by incentives going in the opposite direction, leading them to take on excessive risks. Since both effects are grounded on solid theoretical arguments, the answer of what is the actual relationship between bank internationalization and risk is left to the empirical analysis. In this paper, we study such relationship in the period leading to the financial crisis of 2007-2008. For a sample of 384 listed banks from 56 countries, we calculate two measures of risk for the period from 2001 to 2007 - the expected default frequency (EDF), a market-based and forward-looking indicator, and the Z-score, a balance-sheet-based and backward-looking measure - and relate them to their degree of internationalization. We find robust evidence that international diversification increases bank risk.
\end{abstract}

JEL classification: G21; G32; F23; F36; L22

Keywords: Banks; Risk; Multinational banking; Economic integration; Market structure

\footnotetext{
* We acknowledge financial support from FCT (PTDC7EGE-ECO/114977/2009). We thank participants at the $9^{\text {th }}$ Paris December 2011 Finance Meeting for their comments and suggestions.

**Address for correspondence: Alberto Franco Pozzolo Università degli Studi del Molise, Dipartimento di Scienze Economiche Gestionali e Sociali, Via De Sanctis 86100 Campobasso, Italy. Phone +390874404338, Fax +39087498043. E-mail addresses: magn@iscte.pt (M. A. Gulamhussen); carlos.manuel.pinheiro@cgd.pt (C. Pinheiro); pozzolo@unimol.it (A. F. Pozzolo).
} 


\section{Introduction}

Scholars have traditionally viewed bank internationalization more favorably than regulators and policymakers, on the grounds that opening the banking market to foreign players will result in larger economies of scope and scale, increased competition, and better risk diversification. However, recent research has confirmed part of the fears of policymakers, showing that bank internationalization may induce multinational players to hinder the development of local banks, cherry-pick the best clientele and bypass local regulations.

At first sight, one may classify this debate as a standard discussion between those in favor of free markets and those who believe that certain economic sectors, such as the financial markets, need to be strictly regulated. But the recent financial crisis has clearly shown that market forces, especially in the financial sector, are not always capable of driving the economic system to the first best equilibrium. The call for stricter regulation of financial activities has been strong, with particular attention being paid to the role of the so-called systemically important financial institutions (SIFIs). Many scholars have argued that SIFIs consist exclusively of large multinational banks.

A key issue that has emerged during the recent financial crisis is that multinational banks are too risky. Their default is likely to generate substantial spillover effects to the rest of the system, because they are large and operate in many different countries. Additionally, their complex corporate structures may trigger perverse incentives and excessive risk-taking behavior. The emerging view is indeed that the higher complexity and excessive agency problems associated with multinational banks outweigh the benefits of diversifying the idiosyncratic risks. But since both of these theses are grounded on solid theoretical arguments, we believe that whether multinational banks are more or less risky than domestic institutions is ultimately an empirical issue.

While a vast number of studies have analyzed the determinants of bank risk taking (Vander Vennet et al., 2002; Boyd et al., 2006), the relationship between international diversification and individual bank risk-taking behavior has received much less attention, and most analyses focus only on the U.S. market. In this paper, we analyze this important but overlooked issue by studying the relationship between international diversification and risk in a sample of 384 listed banks headquartered in 56 different countries around the world. Our sample includes both internationally 
diversified and purely domestic banks. We cover the 7 years before the financial crisis, a period during which the riskiness of banks and financial markets increased substantially. This risk-taking behavior eventually led to the worst collapse since the Great Depression. To measure the riskiness of multinational banks, we follow the modified "chop-shop" approach proposed by Laeven and Levine (2007). In this approach, each bank's excess risk is calculated as the difference between its actual risk and the imputed risk level that it would have if its domestic and foreign activities were "chopped" into two parts. With regard to the risk measures, we consider indices that are widely used in the literature: the expected default frequency (EDF), a market-based and forward-looking measure, and the Z-score, a backward-looking measure based on balance-sheet information.

Our work is related to two major streams of the literature. First, we contribute to the analysis of the determinants of bank risk taking by considering a specific type of corporate structure, the multinational company, which is most likely to be affected by all of the problems that standard agency theories have shown to be major causes of corporate risk taking (Jensen and Meckling, 1976; John et al., 2008). Second, we contribute more specifically to the literature analyzing the characteristics of international banks (Buch and DeLong, 2009; Pozzolo, 2009).

Our results show that internationally diversified banks are significantly riskier than domestically oriented banks. Thus, the positive effects of loan and asset diversification in reducing bank risk are outweighed by the negative effects caused by the perverse incentives and complexity associated with large multinational corporations. Our findings are confirmed adopting different estimation techniques and controlling for potential endogeneity.

The rest of the paper is organized as follows. Section 2 relates our research to the previous literature on bank risk taking. Section 3 describes our empirical strategy. Section 4 presents the sources of our information and describes the measures of risk and geographic diversification used in the empirical analyses. Section 5 presents the results. Section 6 concludes this paper.

\section{Related Literature}

The benefits from the diversification of idiosyncratic risks are among the best understood concepts in the economic literature (Cochrane, 2001). From this perspective, the geographic diversification of banks should dampen the effects of 
idiosyncratic shocks and, in this way, reduce their overall riskiness. Although the potential gains from international portfolio diversification are still an object of current research in the finance literature, ${ }^{1}$ Buch et al. (2010) recently showed that bank asset portfolios exhibit a significant home bias. According to this view, geographic diversification should reduce aggregate bank risk.

However, multinational banks typically have access to a much larger set of strategies to increase their risky activities than domestic banks. Additionally, these activities may be hidden from the view of local regulators. Incentive problems lie at the root of these choices. Although international diversification may prove to be a suboptimal decision once one accounts for the costs of increased management complexity, insiders may still support the acquisition of foreign participations if in this way they can obtain private benefits (Jensen and Meckling, 1976; Jensen, 1986). For example, the increased asset liquidity associated with international operations might provide bank managers with more possibilities to trade against the bank's interest (Myers and Rajan, 1998). In this case, geographic diversification may cause an increase in bank risk. In fact, the relevance of incentive issues in bank risk taking was confirmed in a recent study by Laeven and Levine (2009), who show that control problems have a first-order impact on corporate decisions and that banks with less dispersed shareholders are generally riskier.

As we argued above, determining the net effect of the pros and cons of diversification is mainly an empirical issue. However, also in this case the results are rather mixed. Some studies show that geographic diversification increases bank risk. Hughes et al. (1996), studying the effects of U.S. branching deregulation, showed that an increase in the number of U.S. States in which a bank holding company operates increased insolvency risk, whereas a rise in the number of branches per se had the opposite effect. De Nicolò et al. (2004) found that large conglomerate corporations did not exhibit higher levels of risk-taking behavior than average banks in 1995, but did so in 2000. Other studies reached the opposite conclusion. Analyzing US mergers and acquisitions, Zhang (1995) found that geographical diversification leads to lower risk by reducing income variability. Deng et al. (2007) showed that banks that are domestically diversified on both the assets and the liabilities sides pay lower bond spreads, which provide indirect evidence of lower risk. Similarly, Deng and Elyasiani

\footnotetext{
${ }^{1}$ See Karolyi and Stulz (2001) and Stiroh (2009) for a survey of this literature.
} 
(2008) found that geographically diversified banks have lower stock price variability. With regard to international diversification, Amihud et al. (2002) showed that crossborder mergers and acquisitions (M\&As) have no effects on bidders' systematic risk levels, although this result was questioned by Focarelli et al. (2008), who found instead that bidders experience a reduction in their beta (i.e., the correlation of their returns with stock market returns). ${ }^{2}$

\section{Empirical strategy}

\subsection{Econometric model}

Our test of whether a bank's excess risk is a function of its degree of international diversification is based on the following empirical model:

$$
\text { Excess risk } k_{j t}=\alpha+\beta \text { geo div } v_{j t}+\gamma \text { controls }_{j t}+\varepsilon_{j t} \text {, }
$$

where the measures of excess risk and geographic diversification refer to bank $j$ at time $t$; the controls include time-varying bank-specific characteristics as well as time and country dummies; and $\varepsilon_{j t}$ is an error term. To account for the large values of the coefficients of skewness and courtosis of our dependent variables, we trim our data by excluding observations below the $5^{\text {th }}$ percentile and above the $95^{\text {th }}$ percentile, and we estimate the model with standard OLS, robust regression techniques, that give lower weigh to outliers ( $\mathrm{Li}, 1985)$, and quantile regressions evaluated at the median, that identify the regression plane minimizing the sum of the absolute residuals (Cameron and Trivedi, 2009). In robustness tests we use alternative econometric specifications and alternative measures of bank risk and geographic diversification. In the following, we discuss in detail our measures of excess risk taking and geographic diversification as well as the controls introduced in our empirical model.

\subsection{Measures of excess risk}

For each bank $j$, we measure excess risk by comparing the bank's actual risk with the imputed measure that it would have if it were "chopped" into two banks: a geographically diversified bank and a domestic, undiversified bank. If we could measure the actual risk of the geographically diversified bank (ris $\left.k_{i n t}\right)$ and the domestic

\footnotetext{
${ }^{2}$ Our research is also related to the analyses of the risk effects of the diversification of banking activities: Baele et al. (2007) show that a larger share of noninterest income is associated with higher systematic risk, which is measured by the market beta, and Demirgüc-Kunt and Huizinga (2010) also confirm this result with regard to the $\mathrm{Z}$-score.
} 
bank $\left(r i s k_{d o m}\right)$, then the imputed risk of a bank with a share $\varphi$ of internationally diversified activities and a share $(1-\varphi)$ of domestic activities would be $\varphi$ risk $_{\text {int }}+(1-$ $\varphi)$ risk $_{d o m}$. Because we cannot precisely measure the risk of the geographically diversified and the domestic arms of the banks, for each bank $j$, we compute an index of foreign geographical dispersion as follows: first we define the diversity index $\alpha_{j}=$ $\frac{n_{j}}{n_{\max }}$, where $n_{j}$ is the average number of foreign countries in which bank $j$ has a subsidiary during our sample period, and $n_{\max }$ measures the same number for the most internationally diversified bank; then we calculate the excess risk of a geographically diversified bank as the difference between its actual risk and the weighted average value of the risk levels of banks with $\alpha_{j}$ above a given threshold (risk $k_{\text {int }}$ ) and the risk levels of a domestic bank (risk $k_{d o m}$ ), where the weight itself is determined by the bank's degree of international diversification $\alpha_{j}$. Formally, we define excess risk as follows:

$$
\text { Excess risk } k_{j}=\text { risk }_{j}-\left[\alpha_{j} \text { risk }_{i n t}+\left(1-\alpha_{j}\right) \text { risk }_{d o m}\right]
$$

Similar to Laeven and Levine (2007), we define diversified banks as those banks that have an index of geographical dispersion above a threshold of $70 \%$ in our baseline specification. Domestic banks are those with an index of geographical dispersion below a threshold of $30 \%$.

The empirical literature has proposed a large number of measures of bank risk taking. ${ }^{3}$ In our analysis, we use a market-based and forward-looking index, the expected default frequency (EDF) based on Black and Sholes (1973) and Merton (1974), and an accounting and backward-looking indicator, the Z-score.

More precisely, our first measure, the expected default frequency, is the bank's 5-year ahead cumulative EDF provided by Moody's KMV, which is based on the Vasicek-Kealhofer model, as explained in detail by Kealhofer (2003). Following Laeven and Levine (2009), our second measure, the Z-score, is computed as $\frac{C A R+E Q T}{\sigma(R O A)}$, where $C A R$ is the capital-to-total-assets ratio, $E Q T$ is the equity-to-totalassets ratio, and $\sigma(R O A)$ is the standard deviation of the return on assets (ROA) in the previous 3 years. Under the assumption that profits follow a normal distribution, the Zscore measures the number of standard deviations that a bank's ROA has to drop below

\footnotetext{
3 For example, see Berger and De Young (1997), Williams (2004), Garlappi et al. (2006), De Nicolò and Loukoianova (2007), Laeven and Levine (2009), Altunbas et al. (2010), Buch and DeLong (2009), Chiaramonte and Casu (2010), Fiordelisi et al. (2010) and De Haan and Poghosyan (2011).
} 
its expected value before the equity is entirely depleted. Because the Z-score is a negative function of the risk of default (i.e., banks with a higher Z-score are less likely to default), in our estimates we use the opposite of the Z-score, which we call Z'-score, so that a positive sign of its coefficient implies an increase in bank risk, similar to the measure based on EDF.

\subsection{Measures of geographic diversification}

Most conventional empirical studies measure geographic diversification by considering the number of subsidiaries in a corporation or the number of locations in which the corporation is present. Some studies simply use a binary variable indicating whether the corporation is present in a given area (i.e., typically a foreign country). However, these measures do not precisely assess the level and the intensity of banks' geographic diversification and do not account for the trend in international diversification that characterized the banking sector before the recent crisis (Pozzolo, 2009). Therefore, following Gulamhussen et al. (2010), we compute three alternative measures of geographic diversification. Each measure positions the banks over a continuum, with the lower bound corresponding to purely non-diversified (domestic) banks and the upper bound corresponding to the most geographically diversified banks.

Our first measure is a proxy for geographic reach and is formally defined as follows:

$$
\text { geographic reach } h_{j t}=\frac{n_{j, t}}{n_{\max , t}} \text {, }
$$

where $n_{j, t}$ is the number of foreign countries in which the bank $j$ has a subsidiary in year

$t$, and $n_{\max , t}$ is the maximum number of foreign countries in which the most diversified bank has subsidiaries in year t. Clearly, geographic reach is a stock variable, continuous, and bounded between 0 and 1. Purely domestic banks assume a value of 0 , and values close to 1 indicate more geographically dispersed banks. This index normalizes the measure of geographic diversification by accounting for the yearly variation of the most diversified banks.

Our second measure, geographic share, computes the share of assets on a country-by-country basis by considering a bank's asset dispersion across its subsidiaries (similar to Buch and Lipponer, 2007). We compute the difference between the total assets and the foreign assets of the bank's subsidiaries. We then scale this 
difference by the total assets of all bank's subsidiaries. Formally, we calculate the following index:

$$
\text { geographic } \text { share }{ }_{j t}=1-\left(\frac{\text { total subsidiaries assets }- \text { foreign subsidiaries assets }}{\text { total subsidiaries assets }}\right) .
$$

Geographic share is also bounded between 0 and 1, with values close to 0 indicating low geographic diversification and values close to 1 indicating high geographic diversification.

Compared with geographic reach, geographic share conveys more information, in that it considers the incidence of foreign participations in the aggregate activities of a banking group. In fact, the geographic reach of a bank that has 4 foreign subsidiaries, each of which accounts for just $2 \%$ of its total assets, is identical to that of a group that spreads its activities equally across different countries and that has 5 subsidiaries, each of which represents $20 \%$ of the total assets; on the contrary, the geographic share of the two banks is, respectively, 0.08 and 0.80. However, geographic share has the drawback that a bank with just one foreign subsidiary that represents $50 \%$ of its activities is identical to a bank with foreign subsidiaries in 10 different countries, each of which represents $5 \%$ of this bank's total assets.

To account for both the number of foreign countries in which a bank is present and the weight of each activity, we calculated our third measure of diversification, geographic concentration, as a transformed Hirsch-Herfindhal Index (Mercieca et al., 2007). We compute this index based on the total assets of a banking group's foreign participations in each subsidiary in the various foreign countries. ${ }^{4}$ Formally, we define the index as follows:

$$
\text { geographic concentration }_{j t}=1-\sum_{j=1}^{n_{j}}\left(\frac{\text { subsidiary }_{j} \text { assets }}{\text { total subsidiaries assets }^{2}}\right)^{2} .
$$

Geographic concentration is also bounded between 0 and 1, with values close to 0 indicating low geographic diversification and values close to 1 indicating geographically dispersed banks.

\subsection{Other bank characteristics}

Bank riskiness is related to other characteristics than just international diversification. For example, during the recent financial crisis, scholars have forcefully argued that

\footnotetext{
${ }^{4}$ Similar concentration measures can be found in the works of Acharya et al. (2006) and Stiroh and Rumble (2006).
} 
large banks have excessively high risk attitudes because they discount the fact that, in cases of distress, the government will bail them out using public money (i.e., they are too big to fail). At the same time, it is well known that larger banks are more likely to be internationally diversified. Because we are interested in measuring only the partial correlation between geographic diversification and risk, neglecting to control for size might introduce a bias in favor of finding a positive relationship just because larger banks are riskier and more international at the same time. To account for these and other bank characteristics that might potentially bias our results, we include a number of time varying bank-specific controls in our specification.

First, we considered two measures related to size: the logarithm of total assets and that of total operating income. In addition to the too-big-to-fail argument, the asset and loan portfolios and the activities of larger banks are typically far more diversified than those of smaller institutions. This difference obviously impacts the degree of risk that banks take on, independently of their degree of international diversification. In addition, we also include total income, because it measures bank size taking indirectly into account also the role of off-balance sheet activities. Profitability is also correlated with both international diversification and risk: according to the standard meanvariance portfolio model, higher profitability entails higher variability (i.e., higher risk) and, at the same time, it is well known that more profitable banks are more likely to be internationally diversified (Focarelli and Pozzolo, 2001). Moreover, a bank with a high franchise value might be less prone to engaging in risky activities because of the larger losses that it would incur in case of a default. To control for both profitability and franchise value, we therefore include the value of the returns on assets (ROA). In addition, we control for the share of retail deposits over total liabilities, because the funding composition is likely to affect the banks' lending and investing strategies. Finally, since more capitalized banks can tap into riskier projects, we include in our specification the ratio of equity over total assets.

\subsection{Country controls}

Country characteristics, such as the strictness of the regulatory environment, are most likely to have a strong impact on bank strategies and risk. To control for these possibly confounding effects on the relationship between internationalization and risk, we include country dummies in all our specifications. 


\section{Data and summary statistics}

\subsection{Sources}

We focus on commercial banks, a homogeneous group of financial institutions that has been found to have compelling reasons to internationalize their activities (Focarelli and Pozzolo, 2005; Barba et al., 2010). To assemble our data, we first extracted the yearly account and market data from 2001-2007 on all of the listed commercial banks on Bankscope with total assets in excess of US\$ 100 million. We excluded smaller banks, that may face additional challenges and costs in diversifying across borders compared with large banks. We also excluded banks headquartered in off-shore centers, such as Bermuda, Gibraltar, the Virgin Islands or the Cayman Islands, because they typically have less standard business models. We retrieved some missing information from Worldscope, Datastream and individual bank websites, integrating in this way our initial data set. We undertook a painstaking effort to clean and complement the information downloaded from Bankscope and to avoid incongruent and missing data on crucial account and market variables. Our data-assembling exercise yielded an initial sample of 577 commercial banks and 4,039 bank-year observations.

By matching our initial 577 publicly traded banks with the yearly data on the banks' subsidiaries, we obtained a final sample of 384 banks headquartered in 56 countries for which time-varying data on domestic and foreign subsidiaries were available. ${ }^{5}$ Japan and the U.S. have the largest number of banks in our sample, with $17.0 \%$ and $9.4 \%$ of the total number of banks, respectively.

Data on the expected default frequencies (EDF) are from Moody's KMV. When merging our balance sheet information with the risk measures, the number of banks in our sample falls to slightly less than 250 banks, depending on the measure of risk that we used.

\subsection{Summary statistics}

Table 1 presents the summary statistics of the dependent and independent variables in our empirical model. Our two measures of excess risk exhibit great variability. Also

\footnotetext{
${ }^{5}$ The 56 countries in our sample are the following: Australia, Bangladesh, Belgium, Brazil, Canada, China, Colombia, Croatia, Czech Republic, Denmark, Egypt, Estonia, Finland, France, Germany, Greece, Hong Kong, India, Indonesia, Ireland, Israel, Italy, Japan, Jordan, Kenya, Rep. of Korea, Kuwait, Lebanon, Lithuania, Malaysia, the Netherlands, Oman, Pakistan, Peru, Philippines, Poland, Portugal, Qatar, Romania, Saudi Arabia, Singapore, Slovakia, Slovenia, South Africa, Spain, Sri Lanka, Sweden, Switzerland, Taiwan, Thailand, Tunisia, Turkey, United Arab Emirates, United Kingdom, United States, and Venezuela.
} 
geographic reach shows substantial variability. The more geographically diversified commercial banks in our sample exhibit a geographic reach in excess of 0.75 . Examples of these banks include ABN Amro (Netherlands), BNP Paribas (France), Société Générale (France), Citibank (U.S.) and the HSBC (U.K.). Purely domestic banks, that have no foreign subsidiaries, include instead 1st Source Bank (U.S.), Citizens Bank (U.S.), City National Bank (U.S.), Banca Italalease (Italy), Canadian Western Bank (Canada), Howa Bank (Japan), and Daishi Bank (Japan). When measuring geographic diversification in terms of geographic share (i.e., the weight of foreign subsidiaries' assets in subsidiaries' total assets), the most geographically dispersed banks are Deutsche Bank (Germany), Unicredit (Italy) and the Royal Bank of Scotland (U.K.). According to the modified Hirsch-Hirfindhal Index of bank geographic concentration, the most diversified banks are BBVA (Spain), ING (Netherlands) and the National Bank (Greece). Our sample shows high variability also in terms of bank size: BNP Paribas (France), Deutsche Bank (Germany), HSBC (U.K.), ING (The Netherlands), Santander (Spain) and UBS (Switzerland), the largest banks in terms of total assets, are about two order of magnitudes larger than small financial intermediaries such as Citizens Bank, Sunwest Bank, First California Bank (U.S.) and Howa Bank (Japan).

Table 2 presents the mean and median differences of the excess risk values of domestically and internationally oriented banks, where we define a bank as geographically diversified if it has a value of the diversity index above 0.7 and as domestically oriented if it has a value below 0.3 . In the first row of Table 2, we test the null hypothesis that the mean excess risk values for internationally and domestically oriented banks are the same. The values of the statistics of the $t$-test do not allow us to reject the hypothesis of equality of means. Because the distribution of excess risk is mostly skewed to the right, we present in the second row of Table 2 the results of a non-parametric test for the differences in the medians. In this case, we cannot reject the hypothesis of equality of medians for excess Z-score, but excess EDF yields a significant statistic. However, since sample statistics do not fully explain the relationship between bank risk and diversification, we move next to a finer-grained analysis, based on a set of multivariate econometric models. 


\section{Econometric analysis}

\subsection{Baseline specification}

Table 3 reports the baseline results of the estimation of of equation (1), where we include country and year fixed effects in all specifications, and the measures of excess risk are trimmed at the $5 \%$ and $95 \%$ percentiles. $^{6}$

Panels 1-3 of Table 3 report the estimates using the excess EDF as a measure of bank risk and geographic reach as the measure of diversification. Panels 4-6 have the same setup, but present the results obtained measuring excess risk with the Z'-score. Our first estimates are based on OLS (Panels 1 and 4). However, to account for the presence of influential observations and for the non-normality of the dependent variable, we also estimate a robust regression (Panels 2 and 5) and a quantile regression model evaluated at the median (Panels 3 and 6), with standard errors bootstrapped with 100 replications (Efron and Tibshirani, 1993). In both cases, we adopt the same specification used in the OLS estimates.

In Panels 1-3, the coefficient of geographic reach is positive, it ranges from 0.546 to 0.636 , and it is always significantly different from zero at the $1 \%$ level. This finding indicates that there exists a positive, statistically and economically significant relationship between geographic diversification and bank risk: geographically diversified banks have a significantly higher probability of default than similar banks with geographically focused activities. Measuring risk using Z'-score, a backwardlooking and balance-sheet-based measure, gives similar results (Panels 4-6). The coefficient of geographic reach ranges from 6.396 to 7.549 and it is once again statistically significant at the $1 \%$ level. This finding provides further support for the previous evidence.

The coefficients of the other control variables provide additional insights into the determinants of bank risk. Measured by the logarithm of its total assets, bank size has a negative and significant impact on the expected default frequency. This result suggests that larger banks have more opportunities for risk diversification, and that they can benefit from safety nets which influence their ability to weather adverse financial difficulties as compared to smaller financial institutions. In contrast, the statistically insignificant coefficient of the logarithm of total income shows that, for given total of

\footnotetext{
${ }^{6}$ In unreported regressions, available upon request, we verified that including the more extreme valules, the results are even starker than those of Table 3.
} 
assets, banks with larger revenues are equally exposed to the probability of default. Banks with a higher franchise value, which we proxy with the level of returns on assets, also have a lower probability of default, consistent with the view that they are less prone to take on risky activities. The incidence of deposits on total liabilities has an unclear effect on bank risk, but its inclusion does not alter the key findings on bank international diversification. On the contrary, more capitalized banks are less prone to default, as the coefficient estimate of equity to assets is negative and statistically significant in all specifications.

The overall picture emerging from our baseline specification clearly shows that internationally diversified banks with broader geographic footprints are riskier than their peers. In the following, we present the results of a number of additional regressions that test the robustness of our findings.

\subsection{Non-linear effects}

Gulamhussen et al. (2010) show that geographic diversification has an inverse Ushaped effect on bank value. In other words, if a bank is operating in a small number of countries, then international diversification causes the bank's value to increase, but once the bank reaches a given threshold, further expansion abroad has instead a negative effect. In that paper, we argued that this finding might be due to the high costs and the excessive complexity of managing large multinational banks. One possible reason is that the management of very large multinational banks might entail considerable risks. If this were the case, we should find that very large banks have a higher degree of riskiness than what is expected based on the linear relationship estimated above.

To test this hypothesis, we re-estimate the baseline specification substituting our continuous measure of geographic reach with 6 dummies: one for the values of geographic reach that are equal to zero and the other 5 for each quintile of the strictly positive support of the distribution of geographic reach. Panels 1 and 4 of Table 4 report the results for our two different measures of risk. The key finding is that the relationship between international diversification and bank risk increases with the level of diversification. This is consistent with the hypothesis that high levels of international diversification entail substantial agency costs and management complexity, which hinder corporate control, increase the banks' opaqueness and, ultimately, augment their riskiness. In particular, when we measure risk using excess EDF, only the coefficients 
of the dummies for the most geographically diversified banks are statistically significant (i.e., a value of geographic reach above 0.12 , indicating a presence in $12 \%$ of the foreign countries in which the most diversified bank of the sample has subsidiaries). In the case of the Z'-score, the evidence of a non-linear relationship is also confirmed, since the largest coefficients are those of the dummies for the higher quintiles. In all specifications, the coefficients of the other bank-specific controls are in line with the baseline findings.

An additional nonlinearity could be instead related to the level of bank risk. For example, less risky banks might find it beneficial to diversify their activities internationally, reducing their overall riskiness, while for riskier banks agency problems might be more pervasive, leading to a positive relationship between international diversification and bank risk. To verify this additional hypothesis, we have estimated an interquantile regression, testing whether the effect of geographic diversification is different at the $25^{\text {th }}$ and $75^{\text {th }}$ percentiles of the distribution of our measures of risk. The results, presented in Panels 2 and 4 of Table 4, show that the coefficients of the measures of geographic diversification are never statistically significant, suggesting that the effect of international diversification is the same at different levels of bank risk. ${ }^{7}$

\subsection{Alternative measures of geographic diversification}

Table 5 presents the results obtained estimating our empirical model with the two alternative measures of geographic diversification described in Section 3: geographic share (equation (4)) and geographic concentration (equation (5)). Measuring diversification with geographic share (i.e., a function of the share of the foreign subsidiaries' assets over the total value of bank assets), we find a positive but statistically insignificant relationship with excess EDF, and a positive and statistically significant relationship at the $1 \%$ level with excess $Z$ '-score. This result suggests that the dispersion across a large number of foreign countries has a stronger impact on riskiness than the sheer incidence of foreign activities. When we measure diversification using geographic concentration (HHI), which weighs the number of foreign countries in which a bank is present by the size of the foreign activities, the estimated coefficient is indeed positive and statistically significant at the $1 \%$ level for

\footnotetext{
${ }^{7}$ In unreported regressions, available upon request, we have found similar results comparing the effect at the 10th and 90th percentiles.
} 
both risk measures, providing further support to the argument that it is dispersion that entails more risk.

\subsection{Additional robustness checks}

In addition to the two risk measures described above, as a further robustness check we also estimated our empirical model using the excess variability of bank stock returns, a market based and backward looking measure. We collected data from 1999 to 2007 on a weekly basis from Bloomberg, and computed the average standard deviation of stock market returns for three rolling years. Table 6 presents the results of regressing alternatively our three measures of geographic diversification on excess earnings volatility. Excluding the case of geographic share, the results confirm the previous findings of a positive relationship between international diversification and risk.

In a number of additional regressions, that we do not report for space reasons but are available upon request, we performed some further robustness checks. First, we used CDS spreads as a forward-looking measure of bank risk. ${ }^{8}$ We obtained our data from Markit, a commercial data provider (see also Jorion and Zhang, 2007). Unfortunately, merging our data set with this additional information we ended up with a sample of only 75 banks. $^{9}$ Reassuringly, also in this case we found a positive and statistically significant relationship between internationalization and risk. Second, we calculated our measures of excess risk using the average value of banks with a diversity index above $90 \%$ for internationally oriented banks, and the average value of banks with a value below $10 \%$ for domestically oriented banks. The results are also in this case qualitatively unchanged. Finally, we excluded in turn the U.S. and Japan, because these two countries represent $9.4 \%$ and $17.0 \%$ of our sample, respectively. Once again, our previous results remain economically and statistically unchanged.

\subsection{Endogeneity}

In the previous Sections we have been rather careful in presenting our results as partial correlations, avoiding to stress the existence of a causal relationship of international

\footnotetext{
${ }^{8} \mathrm{CDS}$ are contracts that provide insurance against the risk of default of a financial asset in which an insurance buyer pays the insurer a fixed amount (i.e., a defined CDS premium) at regular time intervals until the end of the contract or until the default event occurs. In the event of default, the insurer refunds the CDS holder for the nominal value of the defaulted asset.

${ }^{9}$ Demirgüc-Kunt et al. (2010) face a similar problem of lack of data on CDS spreads when they analyzed the link between bank risk and capital, ending up with a sample of only 33 internationally active banks.
} 
diversification on bank risk. Indeed, many determinants of geographic diversification are the same that underpin bank risk. Finding that more diversified banks are exposed to higher levels of risk does not therefore constitute sufficient proof per se of a causality effect. Indeed, international diversification itself may be an endogenous choice, and commercial banks that decide to pursue riskier business models may decide to do so also by diversifying their activities across national borders.

To uncover the existence of a causal relationship from international diversification to riskiness, we employ three different estimation techniques. First, we re-estimate the baseline specification using bank level fixed effects, therefore controlling for all possible omitted bank specific characteristics that might be correlated with both geographic diversification and excess risk. Clearly, in this way we immunize our model to all the information content of bank cross-section variability. The results of Panels 1 and 4 of Table 7 show that the coefficient of geographic diversification is positive and statistically significant for both measures of bank risk, confirming our previous findings.

Second, we augment the baseline specification including the lagged dependent variable, since our measure of bank value is likely to be time-persistent. We use the generalized method of moments (GMM) developed for dynamic panel data model (Arellano and Bond, 1991; Arellano and Bover, 1995). ${ }^{10}$ Panels 2 and 5 of Table 7 show that indeed the lagged dependent variable is positive and highly statistically significant. Reassuringly, the coefficient of geographic diversification is also in this case positive and statistically significant. Moreover, the value of the Hansen statistic for over-identifying restrictions, testing the hypothesis of lack of correlation between the instruments and residuals, and the value of the test for absence of second-order serial correlation of residuals both point to the validity of our specification.

Finally we use a two stage approach, instrumenting the measure of degree of international diversification with: (i) its two most recent lagged values; (ii) the geographic distance of the country hosting the parent company from all other countries in our sample weighted by each country's total GDP, an asymmetric measure of the vicinity to foreign markets that might be used for geographic diversification; (iii) the share of geographically diversified banks in the country, as indirect evidence of an environment that favors internationalization; (iv) a dummy variable for banks that are

\footnotetext{
${ }^{10}$ Estimation is conducted using the XTABOND2 program for Stata written by David Roodman (2006).
} 
included in the Standard and Poor's 500 on the grounds that they might be better equipped to finance geographic diversification; (v) an index of regulatory quality (Kaufman et al., 2009); and (vi) an index of economic freedom, as proxies of how much the institutional environment is favorable to international diversification. ${ }^{11}$ The results reported in Panels 3 and 6 of Table 7 show that also in this case the coefficients of geographic diversification are positive and statistically significant.

\section{Conclusions}

The design of a new regulatory framework capable of addressing the many fallacies uncovered by the recent financial crisis requires a precise understanding of the characteristics of the different business models followed by banks and of their riskiness. One of the issues that has captured much attention from regulators and policymakers is the international dimension of the financial markets, particularly the role of multinational players.

In this paper we show that multinational banks are indeed riskier. The higher value entailed by international diversification found by Gulamhussen et al. (2010) comes therefore at a cost: multinational banks, especially the largest players that have subsidiaries all over the world, have a higher expected probability of default, as measured by EDFs, lower Z-scores, and higher stock price earnings volatility. Several robustness checks indicate that our findings are not driven by few influential observations, or biased by endogeneity problems.

As there are no grounds to exclude the benefits from the diversification of the idiosyncratic shocks to the asset and loan portfolios, we can infer that higher riskiness is due to the business model chosen by multinational banks. In particular, it is most likely that incentive problems lie at the root of this higher riskiness. Multinational banks are not riskier per se, but they can take on more risk if the management decides to do so. A regulatory framework that increases the costs of holding cross-border activities and participations might have a negative adverse-selection effect such that only those who are ready to assume high levels of risk will diversify internationally. As recently argued by Diamond and Rajan (2009), a better approach would be to directly

\footnotetext{
${ }^{11}$ Regulatory quality is from the World Bank data base (Worldwide Governance Indicators, available at www.worldbank.org/wbi/governance), as in Kaufman et al. (2009); economic freedom is from the Heritage Foundation (http://www.heritage.org/Index/), and it is an average of the scores of ten country indicators: Business Freedom, Trade Freedom, Fiscal Freedom, Government Spending, Monetary Freedom, Investment Freedom, Financial Freedom, Property rights, Freedom from Corruption, Labor Freedom.
} 
adjust the mechanism behind the incentives that lead multinational banks to take on excessive levels of risk. 


\section{References}

Acharya, V.V., I. Hasan and A. Saunders, 2006, Should banks be diversified? Evidence from individual bank loan portfolios, Journal of Business 79(3), 1355-1412.

Amihud, Y., G. DeLong and A. Saunders, 2002, The effects of cross-border bank mergers on bank risk and value, Journal of International Money and Finance 21(6), 857-877.

Altunbas, Y., L. Gambacorta and D. Marques-Ibanez, 2010, Does monetary policy affect bank risk-taking? ECB Working Paper no. 1166/10.

Arellano, M., and S.R. Bond, 1991, Some tests of specification for panel data: Monte Carlo evidence and an application to employment equations, Review of Economic Studies 58, 277-297.

Arellano, M., and O. Bover, 1995, Another look at the instrumental variable estimation of error-components models, Journal of Econometrics 68, 29-51.

Baele, L., O. De Jonghe and R. Vander Vennet, 2007, Does the stock market value bank diversification? Journal of Banking and Finance 31(7), 1999-2023.

Barba Navaretti, G., Calzolari, G., Pozzolo, A.F., Levi, M., 2010, Multinational Banking in Europe: Financial Stability and Regulatory Implications Lessons from the Financial Crisis. Economic Policy 25, 703-753.

Berger, A.N. and R. De Young, 1997, Problem loans and cost efficiency in commercial banking, Journal of Banking and Finance 21(6), 849-870.

Black, F. and M. Scholes, 1973, The pricing of options and corporate liabilities, Journal of Political Economy 81(4), 637-659.

Boyd, J.H., G. De Nicolò and A.M. Jalal, 2006, Bank risk-taking and competition revisited: New theory and new evidence, IMF Working Paper no. 06/297.

Buch, C.M. and A. Lipponer, 2007, FDI versus exports: Evidence from German banks, Journal of Banking and Finance 31(3), 805-826.

Buch, C.M. and G.L. DeLong, 2009, Banking globalization: international consolidation and mergers in banking, in Berger, A.N., P. Molyneux, and J.O. Wilson eds.: The Oxford Book of Banking, Oxford University Press.

Buch, C.M., J.C. Driscoll and C. Ostergaard, 2010, Cross-Border Diversification in Bank Asset Portfolios, International Finance 13(1), 79-108.

Cameron, A.C. and P.K. Trivedi, 2009, Microeconometrics using Stata, Stata Press USA. 
Chiaramonte, L. and B. Casu, 2010, Are CDS spreads a good proxy of bank risk? Evidence from the financial crisis, Working paper no. 05/10.

Cochrane, J., 2001, Asset Pricing, Princeton University Press, Princeton NJ.

De Haan, J. and T. Poghosyan, 2011, Bank size, market concentration, and bank earnings volatility in the U.S., DNB Working paper no. 282.

De Nicolò, G.D., P. Bartholomew, J. Zaman and M. Zephirin, 2004, Bank consolidation, internationalization, and conglomeration: trends and implications for financial risk, Financial Markets, Institutions and Instruments 13, 173-217.

De Nicolò, G. and E. Loukoianova, 2007, Bank ownership, market structure and risk, IMF Working paper no. 215.

Demirgüç-Kunt, A., E. Detragiache and O. Merrouche, 2010, Bank capital: lessons from the financial crisis, The World Bank Policy Research Working Paper no. $5473 / 10$.

Demirgüç-Kunt A. and H. Huizinga, 2010, Bank activity and funding strategies: The impact on risk and returns, Journal of Financial Economics 98(3), 626-650.

Deng, S., E. Elyasiani and C. Mao, 2007, Diversification and the cost of debt of bank holding companies, Journal of Banking and Finance 31(12), 2453-2473.

Deng, S. and E. Elyasiani, 2008, Geographic diversification, bank holding company value, and risk, Journal of Money, Credit and Banking 40(6), 1217-1238.

Diamond W. D. and R. Rajan, 2009, The credit crisis: Conjectures about causes and remedies, NBER Working Paper no. 14739.

Efron B. and R.J. Tibshirani, 1993, An introduction to the bootstrap, New York, Chapman and Hall.

Fiordelisi, F., D. Marques-Ibanez and P. Molyneux, 2010, Efficiency and risk in European banking, ECB Working paper no. 1211.

Focarelli, D. and A.F. Pozzolo, 2001, The patterns of cross-border bank mergers and shareholdings in OECD countries, Journal of Banking and Finance 25(12), 23052337.

Focarelli, D. and A.F. Pozzolo, 2005, Where do banks expand abroad? An empirical analysis, Journal of Business 78(6), 2435-2463.

Focarelli D., A.F. Pozzolo and C. Salleo, 2008, Do M\&As in the financial industry modify systematic risk?, mimeo.

Garlappi, L., T. Shu and H. Yan, 2006, Default risk, shareholder advantage, and stock returns, The Review of Financial Studies 21(6), 2743-2778. 
Gulamhussen, M.A., C. Pinheiro and A.F. Pozzolo, 2010, Do multinational banks create or destroy economic value? MoFiR Working Paper no. 36.

Hughes, J. P., W. Lang, L. J. Mester and C. Moon, 1996, Efficient banking under interstate branching, Journal of Money, Credit and Banking 28(4), 1045-1071.

Jensen, M.C., 1986, Agency costs of free cash flow, corporate finance, and takeovers. American Economic Review 76(2) Papers and Proceedings, 323-329.

Jensen M.C. and W.H. Meckling, 1976, Theory of the firm: Managerial behavior, agency costs, and ownership structure, Journal of Financial Economics 3(4), 305360.

John, K., L. Litov and B. Yeung, 2008, Corporate governance and managerial risk taking: Theory and evidence," Journal of Finance 63(4), 1679-1728.

Jorion, P. and G. Zhang, 2007, Good and bad credit contagion: Evidence from credit default swaps, Journal of Banking and Finance 84(3), 860-883.

Karolyi, G.A. and R.M. Stulz. (2002), Are financial assets priced locally or globally? in G. Constantinides, M. Harris, and R. M. Stulz eds.: Handbook of the Economics of Finance, North-Holland.

Kaufman, Daniel, Aart Kraay, and Massimo Mastruzzi, 2009, Governance matters VIII: Aggregate and individual governance indicators 1996-2008, World Bank Working paper no. 4978.

Kealhofer, S., 2003, Quantifying credit risk II: debt valuation, Financial Analysts Journal 59(3), 30-44.

Laeven, L. and R. Levine, 2007, Is there a diversification discount in financial conglomerates? Journal of Financial Economics 85(2), 331-367.

Laeven, L. and R. Levine, 2009, Bank governance, regulation and risk taking, Journal of Financial Economics 93(2), 259-275.

Li, G., 1985, Robust regression, in Shapes, D., C. Hoaglin, F. Mosteller, and J.W. Tukey eds.: Exploring Data Tables, Trends, Wiley, New York.

Mercieca, S., K. Schaek and S. Wolfe, 2007, Small European banks: Benefits from diversification? Journal of Banking and Finance 31(7), 1975-1998.

Merton, R.C., 1974, On the pricing of corporate debt: the risk structure of interest rates, Journal of Finance 29(2), 449-470.

Myers, S.C. and R. Rajan, 1998, The paradox of liquidity, Quarterly Journal of Economics 113(3), 733-771. 
Pozzolo, A.F., 2009, Bank cross-border mergers and acquisitions (causes, consequences and recent trends) in Alessandrini, P., M. Fratianni, M., and A. Zazzaro eds.: The Changing Geography of Banking and Finance, Norwell, Springer.

Roodman, D.M., 2006, How to do xtabond2: an introduction to "difference" and "system" GMM in Stata, Center for Global Development, Working paper no. 103.

Stiroh, K.J., 2009, Diversification in banking, Berger, A.N., P. Molyneux, and J.O. Wilson eds.: The Oxford Book of Banking, Oxford University Press.

Stiroh, K.J, and A. Rumble, 2006, The dark side of diversification: The case of U.S. financial holding companies, Journal of Banking and Finance 30(8), 2131-2161.

Vander Vennet, R., 2002, Cost and profit efficiency of financial conglomerates and universal banks in Europe, Journal of Money, Credit and Banking 34(1), 254-282.

Vander Vennet, R., O. De Jonghe and L. Baele, 2004, Bank Risks and the Business Cycle, University of Ghent Working Paper no. 04/264.

Williams, J., 2004, Determining management behaviour in European banking, Journal of Banking and Finance 28(10), 2427-2460.

Zhang, H., 1995, Wealth effects of U.S. bank takeovers, Applied Financial Economics 5(5), 329-336. 
Table 1

\section{Summary statistics}

Excess value is defined as the difference between the actual risk level of bank $_{j}$ and its adjusted risk, as our proxy for risk. Adjusted Risk $k_{j}=\alpha_{j t}$ Risk $_{i n t}+\left(1-\alpha_{j}\right)$ Risk $_{\text {dom }}$, where Risk $k_{i n t}$ is the average Risk level of the banks with international diversification levels above the $70 \%$ threshold (i.e., highly diversified multinational commercial banks), and Risk $k_{d o m}$ represents the average Risk level of the banks equal to or below the $30 \%$ threshold. We computed the excess values of the following risk measures: (i) the 5-year expected default frequency (EDF), which proxies the likelihood to default; (ii) a transformed $Z^{\prime}$-score, which is the symmetric value of $(C A R+E Q T) / \sigma(R O A)$ ) that gauges the proximity to default, where CAR is the capital asset ratio, EQT is the equity-to-assets ratio, and $\sigma(\mathrm{ROA})$ is the volatility of assets; (vi) the earnings volatility, which is computed with a threeyear rolling widow. For bank $j, \alpha$ is the index of geographical dispersion in foreign countries, where $\alpha_{j}=n_{j} / n_{\max }, n_{j}$ is the number of foreign countries in which bank $j$ has a subsidiary, and $n_{\max }$ is the maximum number of foreign countries in which the most diversified bank has subsidiaries. Geographic diversity is the ratio of $n_{j, t}$ to $n_{\max , t}$, where $n_{j t}$ is the number of foreign countries in which bank $j$ has a subsidiary in year $t$, and $n_{\max , t}$ is the maximum number of foreign countries in which the most diversified bank has subsidiaries in year $t$. Two other measures of geographic diversification include the following: the geographic dispersion of subsidiaries (geographic share), which is estimated by 1 - [(total subsidiaries assets - foreign subsidiaries assets) / (total subsidiaries assets)]; and the subsidiaries concentration, which is proxied by a transformed HirschHerfindhal index (HHI) $\left.\left(1-\sum_{\mathrm{j}} \text { (subsidiary }_{j} \text { assets/total subsidiaries assets }\right)^{2}\right)$. The bank controls include the following: (i) the logarithm of total assets (log assets); (ii) the logarithm of total operating income (log income); (iii) ROA as a proxy for profitability; (iv) access to funding, which is proxied by the ratio of deposits to liabilities; and (v) capitalization which is proxied by equity to assets.

\begin{tabular}{|c|c|c|c|c|}
\hline$\underline{\text { Variable }}$ & $\begin{array}{c}\text { Mean } \\
\text { St. Dev }\end{array}$ & $\begin{array}{l}\text { Coefficient } \\
\text { of variation }\end{array}$ & $1^{\text {st }}$ percentile & $\begin{array}{c}99^{\text {th }} \\
\text { percentile }\end{array}$ \\
\hline \multicolumn{5}{|l|}{ Baseline } \\
\hline \multirow[t]{2}{*}{ excess EDF } & 0.02 & 44,00 & -0.60 & 3.74 \\
\hline & 0.88 & & & \\
\hline \multirow[t]{2}{*}{ excess $Z^{\prime}$-score } & -0.20 & $-16,90$ & -5.46 & 11.62 \\
\hline & 3.38 & & & \\
\hline \multirow[t]{2}{*}{ excess earnings volatility (rolling window) } & 0.01 & 86.00 & -0.39 & 4.12 \\
\hline & 0.86 & & & \\
\hline \multirow[t]{2}{*}{ geographic reach $\left(\mathrm{n} / \mathrm{n}_{\max }\right)$} & 0.07 & 2,29 & 0.00 & 0.81 \\
\hline & 0.16 & & & \\
\hline \multirow[t]{2}{*}{ geographic share } & 0.17 & 1,82 & 0.00 & 1.00 \\
\hline & 0.31 & & & \\
\hline \multirow[t]{2}{*}{ geographic concentration (HHI) } & 0.17 & 1,47 & 0.00 & 0.80 \\
\hline & 0.25 & & & \\
\hline \multirow[t]{2}{*}{ assets } & $1,511.52$ & 1.14 & 171.01 & $9,119.74$ \\
\hline & $1,722.22$ & & & \\
\hline \multirow[t]{2}{*}{ income } & 247.25 & 1.03 & 24.11 & $1,347.15$ \\
\hline & 254.41 & & & \\
\hline \multirow[t]{2}{*}{ ROA } & 1.04 & 1,37 & -2.87 & 5.08 \\
\hline & 1.42 & & & \\
\hline \multirow[t]{2}{*}{ deposits to liabilities } & 0.88 & 0,18 & 0.18 & 1.00 \\
\hline & 0.16 & & & \\
\hline \multirow[t]{2}{*}{ equity to assets } & 0.09 & 0,67 & 0.01 & 0.32 \\
\hline & 0.06 & & & \\
\hline
\end{tabular}




\section{Table 2}

Excess risk for diversified banks

Excess risk is defined as the difference between the actual risk level of bank and its adjusted risk level: Adjusted Risk $_{j}=\alpha_{j t}$ Risk $_{i n t}+\left(1-\alpha_{j}\right)$ Risk $_{\text {dom }}$, where Riskint is the average Risk level of the banks with international diversification levels above the $70 \%$ threshold (i.e., highly diversified multinational commercial banks), and Risk $_{d o m}$ represents the average Risk level of the banks equal to or below the 30\% threshold. We computed the excess values of the following risk measures: (i) the 5-year expected default frequency (EDF), which proxies the likelihood to default; (ii) a transformed $Z^{\prime}$-score, which is equal to the symmetric value of $(C A R+E Q T) / \sigma(R O A)$ that gauges the proximity to default, where CAR is the capital asset ratio, EQT is the equity-to-assets ratio, and $\sigma(\mathrm{ROA})$ is the volatility of assets. We trimmed excess risk at the $5^{\text {th }}$ and $95^{\text {th }}$ percentiles. Significance at the $1 \%, 5 \%$, and $10 \%$ levels is denoted by $* * *, * *$, and $*$, respectively.

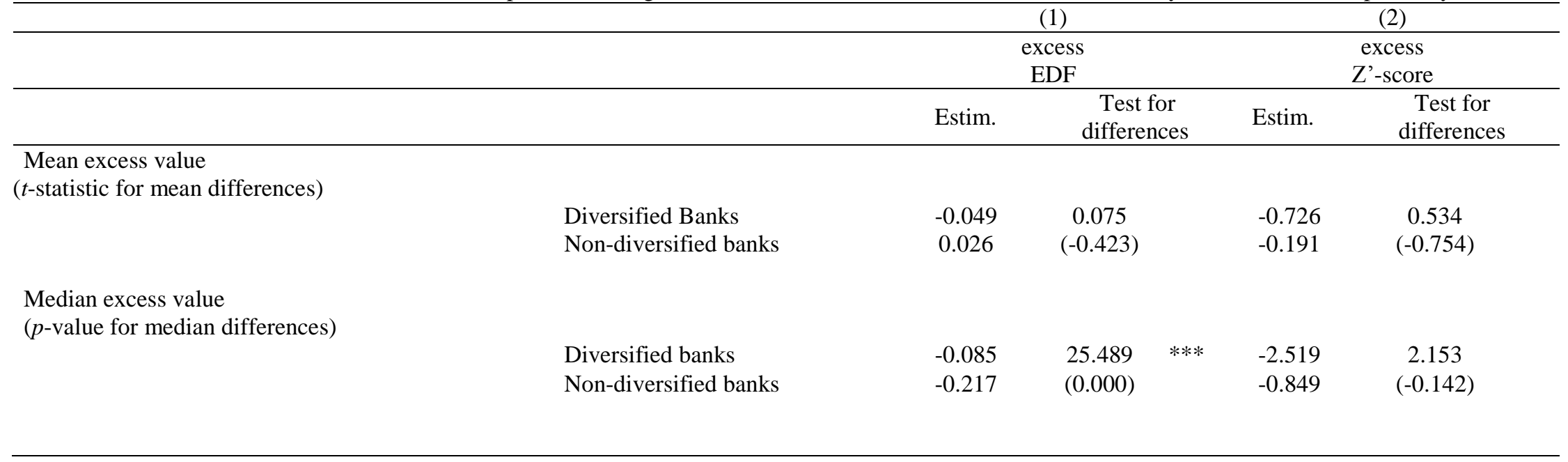


Table 3

Geographic reach and bank risk - baseline specification

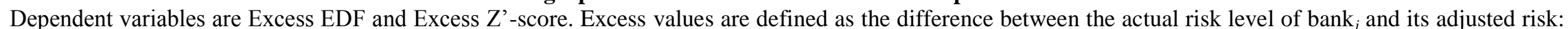
Adjusted Risk ${ }_{j}=\alpha_{j t}$ Risk $_{i n t}+\left(1-\alpha_{j}\right)$ Risk $_{\text {dom }}$, where Risk $k_{\text {int }}$ is the average Risk level of the banks with international diversification levels above the $70 \%$ threshold (i.e., highly diversified multinational commercial banks), and Risk ${ }_{\text {dom }}$ represents the average Risk level of the banks equal to or below the $30 \%$ threshold. We computed the excess values of the following risk measures: (i) the 5-year expected default frequency (EDF), which proxies the likelihood to default; (ii) a transformed $\mathrm{Z}^{\prime}$-score, which is the symmetric value of $(C A R+E Q T) / \sigma(R O A)$ ) that gauges the proximity to default, where CAR is the capital asset ratio, EQT is the equity-to-assets ratio, and $\sigma(\mathrm{ROA})$ is the volatility of assets. For bank $j, \alpha$ is the index of geographical dispersion in foreign countries, where $\alpha_{j}=n_{j} / n_{\text {max }}, n_{j}$ is the number of foreign countries in which bank $j$ has a subsidiary, and $n_{\max }$ is the maximum number of foreign countries in which the most diversified bank has subsidiaries. Geographic reach is the ratio of $n_{j, t}$ to $n_{\max , t}$, where $n_{j t}$ is the number of foreign countries in which bank $j$ has a subsidiary in year $t$, and $n_{\text {max }, t}$ is the maximum number of foreign countries in which the most diversified bank has subsidiaries in year $t$. The bank controls include the following: (i) the logarithm of total assets (log assets); (ii) the logarithm of total operating income (log income); (iii) ROA as a proxy for profitability; (iv) access to funding, which is proxied by the ratio of deposits to liabilities; and (v) capitalization which is proxied by equity to assets. We included but do not report the country and year fixed effects. We trimmed excess risk at the $5^{\text {th }}$ and $95^{\text {th }}$ percentiles. The p-values are in parentheses. Significance at the $1 \%, 5 \%$, and $10 \%$ levels is denoted by $* * *, * *$, and $*$, respectively.

(1)

(2)

(3)

(4)

(5)

(6)

\begin{tabular}{|c|c|c|c|c|c|c|c|c|c|c|c|c|}
\hline \multirow[b]{3}{*}{ geographic reach } & \multicolumn{6}{|c|}{ Excess EDF } & \multicolumn{6}{|c|}{ Excess Z'-score } \\
\hline & \multicolumn{2}{|c|}{ OLS reg. } & \multicolumn{2}{|c|}{ Robust reg. } & \multicolumn{2}{|c|}{ Median reg. } & \multicolumn{2}{|c|}{ OLS reg. } & \multicolumn{2}{|c|}{ Robust reg. } & \multicolumn{2}{|c|}{ Median reg. } \\
\hline & $\begin{array}{c}0.546 \\
(0.000)\end{array}$ & $* * *$ & $\begin{array}{c}0.636 \\
(0.000)\end{array}$ & $* * *$ & $\begin{array}{c}0.604 \\
(0.000)\end{array}$ & $* * *$ & $\begin{array}{c}6.396 \\
(0.000)\end{array}$ & $* * *$ & $\begin{array}{c}7.136 \\
(0.000)\end{array}$ & $* * *$ & $\begin{array}{c}7.549 \\
(0.000)\end{array}$ & $* * *$ \\
\hline $\log$ of assets & $\begin{array}{l}-0.120 \\
(0.000)\end{array}$ & $* * *$ & $\begin{array}{l}-0.101 \\
(0.000)\end{array}$ & $* * *$ & $\begin{array}{c}-0.086 \\
(0.009)\end{array}$ & $* * *$ & $\begin{array}{l}-1.025 \\
(0.000)\end{array}$ & $* * *$ & $\begin{array}{l}-0.530 \\
(0.007)\end{array}$ & $* * *$ & $\begin{array}{l}-1.092 \\
(0.000)\end{array}$ & $* * *$ \\
\hline log of income & $\begin{array}{l}-0.001 \\
(0.964)\end{array}$ & & $\begin{array}{l}-0.023 \\
(0.244)\end{array}$ & & $\begin{array}{c}-0.017 \\
(0.550)\end{array}$ & & $\begin{array}{c}0.228 \\
(0.293)\end{array}$ & & $\begin{array}{c}0.217 \\
(0.142)\end{array}$ & & $\begin{array}{c}0.228 \\
(0.111)\end{array}$ & \\
\hline $\mathrm{ROA}$ & $\begin{array}{l}-0.055 \\
(0.002)\end{array}$ & $* * *$ & $\begin{array}{c}-0.057 \\
(0.000)\end{array}$ & $* * *$ & $\begin{array}{c}-0.069 \\
(0.006)\end{array}$ & $* * *$ & $\begin{array}{l}-1.300 \\
(0.000)\end{array}$ & $* * *$ & $\begin{array}{l}-1.400 \\
(0.000)\end{array}$ & $* * *$ & $\begin{array}{l}-0.960 \\
(0.000)\end{array}$ & $* * *$ \\
\hline deposits to liabilities & $\begin{array}{c}0.065 \\
(0.450)\end{array}$ & & $\begin{array}{c}0.229 \\
(0.000)\end{array}$ & $* * *$ & $\begin{array}{c}0.139 \\
(0.102)\end{array}$ & & $\begin{array}{c}1.066 \\
(0.147)\end{array}$ & & $\begin{array}{l}-1.116 \\
(0.026)\end{array}$ & $* *$ & $\begin{array}{c}0.735 \\
(0.260)\end{array}$ & \\
\hline equity to assets & $\begin{array}{c}-0.654 \\
(0.099)\end{array}$ & $*$ & $\begin{array}{l}-2.650 \\
(0.000)\end{array}$ & $* * *$ & $\begin{array}{l}-1.148 \\
(0.181)\end{array}$ & & $\begin{array}{c}-12.130 \\
(0.006)\end{array}$ & $* * *$ & $\begin{array}{l}-9.092 \\
(0.003)\end{array}$ & $* * *$ & $\begin{array}{l}-3.167 \\
(0.245)\end{array}$ & \\
\hline Country effects & Yes & & Yes & & Yes & & Yes & & Yes & & Yes & \\
\hline Year effects & Yes & & Yes & & Yes & & Yes & & Yes & & Yes & \\
\hline Number of observations & 1,033 & & 1,033 & & 1,033 & & 940 & & 940 & & 1,283 & \\
\hline
\end{tabular}


Geographic reach and bank risk - non-linear effects

Table 4

Dependent variables are Excess EDF and Excess Z'-score. Excess values are defined as the difference between the actual risk

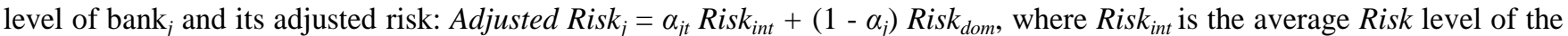
banks with international diversification levels above the $70 \%$ threshold (i.e., highly diversified multinational commercial banks), and Risk $k_{d o m}$ represents the average Risk level of the banks equal to or below the $30 \%$ threshold. We computed the excess values of the following risk measures: (i) the 5-year expected default frequency (EDF), which proxies the likelihood to default; (ii) a transformed $\mathrm{Z}^{\prime}$-score, which is the symmetric value of $\left.(C A R+E Q T) / \sigma(R O A)\right)$ that gauges the proximity to default, where CAR is the capital asset ratio, EQT is the equity-to-assets ratio, and $\sigma(\mathrm{ROA})$ is the volatility of assets. For bank $j, \alpha$ is the index of geographical dispersion in foreign countries, where $\alpha_{j}=n_{j} / n_{\max }$, $n_{j}$ is the number of foreign countries in which bank $j$ has a subsidiary, and $n_{\max }$ is the maximum number of foreign countries in which the most diversified bank has subsidiaries. Geographic reach is the ratio of $n_{j, t}$ to $n_{\text {max, } t}$, where $n_{j t}$ is the number of foreign countries in which bank $j$ has a subsidiary in year $t$, and $n_{\text {max, } t}$ is the maximum number of foreign countries in which the most diversified bank has subsidiaries in year $t$. The bank controls include the following: (i) the logarithm of total assets (log assets); (ii) the logarithm of total operating income (log income); (iii) ROA as a proxy for profitability; (iv) access to funding, which is proxied by the ratio of deposits to liabilities; and (v) capitalization which is proxied by equity to assets. Estimation is with robust regression techniques. We included but do not report the country and year fixed effects. We trimmed excess risk at the $5^{\text {th }}$ and $95^{\text {th }}$ percentiles. The p-values are in parentheses. Significance at the $1 \%, 5 \%$, and $10 \%$ levels is denoted by $* * *, * *$, and $*$, respectively.

(1)

(2)

(3)

(4)

\begin{tabular}{|c|c|c|c|c|c|c|c|c|}
\hline & \multicolumn{4}{|c|}{ Excess EDF } & \multicolumn{4}{|c|}{ Excess Z'-score } \\
\hline & $\begin{array}{l}\text { Splitting geo } \\
\text { reach }\end{array}$ & raphic & $\begin{array}{c}\text { Interquant } \\
\text { reg. }\end{array}$ & & $\begin{array}{c}\text { Splitting geog } \\
\text { reach }\end{array}$ & raphic & $\begin{array}{c}\text { Interquant } \\
\text { reg. }\end{array}$ & \\
\hline geographic reach & & & $\begin{array}{r}-0.013 \\
(0.876)\end{array}$ & & & & $\begin{array}{r}-0.505 \\
(0.747)\end{array}$ & \\
\hline geographic reach - Geon2 & $\begin{array}{r}0.035 \\
(0.228)\end{array}$ & & & & $\begin{array}{r}0.754 \\
(0.000)\end{array}$ & $* * *$ & & \\
\hline geographic reach - Geon3 & $\begin{array}{r}0.036 \\
(0.350)\end{array}$ & & & & $\begin{array}{r}0.479 \\
(0.065)\end{array}$ & $*$ & & \\
\hline geographic reach - Geon4 & $\begin{array}{r}0.024 \\
(0.520)\end{array}$ & & & & $\begin{array}{r}0.822 \\
(0.001)\end{array}$ & $* * *$ & & \\
\hline geographic reach - Geon5 & $\begin{array}{r}0.122 \\
(0.002)\end{array}$ & $* * *$ & & & $\begin{array}{r}1.383 \\
(0.000)\end{array}$ & $* * *$ & & \\
\hline geographic reach - Geon6 & $\begin{array}{r}0.387 \\
(0.000)\end{array}$ & **** & & & $\begin{array}{r}4.271 \\
(0000)\end{array}$ & $* * *$ & & \\
\hline $\log$ of assets & $\begin{array}{r}-0.111 \\
(0.000)\end{array}$ & $* * *$ & $\begin{array}{r}-0.094 \\
(0.118)\end{array}$ & & $\begin{array}{r}-0.846 \\
(0.000)\end{array}$ & $* * *$ & $\begin{array}{r}0.485 \\
(0.241)\end{array}$ & \\
\hline log of income & $\begin{array}{r}-0.024 \\
(0.256)\end{array}$ & & $\begin{array}{r}0.011 \\
(0.836)\end{array}$ & $* * *$ & $\begin{array}{r}0.236 \\
(0.112)\end{array}$ & & $\begin{array}{r}-0.190 \\
(0.429)\end{array}$ & \\
\hline ROA & $\begin{array}{r}-0.043 \\
(0.007)\end{array}$ & $* * *$ & $\begin{array}{r}-0.003 \\
(0.935)\end{array}$ & & $\begin{array}{l}-1.086 \\
(0.000)\end{array}$ & $* * *$ & $\begin{array}{r}-0.462 \\
(0.039)\end{array}$ & $* *$ \\
\hline deposits to liabilities & $\begin{array}{r}0.149 \\
(0.038)\end{array}$ & $* *$ & $\begin{array}{r}-0.279 \\
(0.086)\end{array}$ & $*$ & $\begin{array}{r}-0.884 \\
(0.079)\end{array}$ & $*$ & $\begin{array}{r}1.740 \\
(0.257)\end{array}$ & \\
\hline equity to assets & $\begin{array}{l}-2.606 \\
(0.000)\end{array}$ & $* * *$ & $\begin{array}{r}-0.559 \\
(0.539)\end{array}$ & & $\begin{array}{r}-7.081 \\
(0.018)\end{array}$ & $* *$ & $\begin{array}{r}1.260 \\
(0.804)\end{array}$ & \\
\hline Country effects & Yes & & Yes & & Yes & & Yes & \\
\hline Year effects & Yes & & Yes & & Yes & & Yes & \\
\hline Number of observations & 940 & & 1,033 & & 855 & & 1,283 & \\
\hline
\end{tabular}


Geographic reach and bank risk - alternative measures of geographic diversification

Table 5

Dependent variables are Excess EDF and Excess Z'-score. Excess values are defined as the difference between the actual risk level of bank $k_{j}$ and its adjusted risk: Adjusted Risk $k_{j}=\alpha_{j t}$ Risk $_{i n t}+\left(1-\alpha_{j}\right)$ Risk $_{\text {dom }}$, where Risk $k_{\text {int }}$ is the average Risk level of the banks with international diversification levels above the $70 \%$ threshold (i.e., highly diversified multinational commercial banks), and Risk $k_{d o m}$ represents the average Risk level of the banks equal to or below the $30 \%$ threshold. We computed the excess values of the following risk measures: (i) the 5-year expected default frequency (EDF), which proxies the likelihood to default; (ii) a transformed $Z^{\prime}$-score, which is the symmetric value of $\left.(C A R+E Q T) / \sigma(R O A)\right)$ that gauges the proximity to default, where CAR is the capital asset ratio, EQT is the equity-to-assets ratio, and $\sigma(\mathrm{ROA})$ is the volatility of assets. For bank $j, \alpha$ is the index of geographical dispersion in foreign countries, where $\alpha_{j}=n_{j} / n_{\max }, n_{j}$ is the number of foreign countries in which bank $j$ has a subsidiary, and $n_{\max }$ is the maximum number of foreign countries in which the most diversified bank has subsidiaries. The alternative measures of geographic diversification include the following: (i) the subsidiaries concentration, which is proxied by a transformed Hirsch-Herfindhal index (HHI) $\left(1-\sum_{\mathrm{j}}\left(\operatorname{subsidiary}_{j}\right.\right.$ assets/total subsidiaries assets) ${ }^{2}$ ); and (ii) the geographic dispersion of subsidiaries (geographic share), which is estimated by $1-[($ total subsidiaries assets - foreign subsidiaries assets) / (total subsidiaries assets)]. The bank controls include the following: (i) the logarithm of total assets (log assets); (ii) the logarithm of total operating income (log income); (iii) ROA as a proxy for profitability; (iv) access to funding, which is proxied by the ratio of deposits to liabilities; and (v) capitalization which is proxied by equity to assets. Estimation is with robust regression techniques. We included but do not report the country and year fixed effects. We trimmed excess risk at the $5^{\text {th }}$ and $95^{\text {th }}$ percentiles. The p-values are in parentheses. Significance at the $1 \%, 5 \%$, and $10 \%$ levels is denoted by $* * * * *$, and *, respectively.

(1)

(2)

(3)

(4)

\begin{tabular}{|c|c|c|c|c|c|c|c|c|}
\hline \multirow[b]{2}{*}{ geographic share } & \multicolumn{4}{|c|}{ Excess EDF } & \multicolumn{4}{|c|}{ Excess Z'-score } \\
\hline & & & $\begin{array}{c}0.012 \\
(0.764)\end{array}$ & & & & $\begin{array}{c}0.965 \\
(0.000)\end{array}$ & $* * *$ \\
\hline geographic concentration & $\begin{array}{c}0.143 \\
(0.011)\end{array}$ & $* *$ & & & $\begin{array}{c}2.417 \\
(0.000)\end{array}$ & $* * *$ & & \\
\hline $\log$ of assets & $\begin{array}{l}-0.017 \\
(0.610)\end{array}$ & & $\begin{array}{c}-0.020 \\
(0.545)\end{array}$ & & $\begin{array}{l}-0.777 \\
(0.000)\end{array}$ & $* * *$ & $\begin{array}{c}-0.694 \\
(0.000)\end{array}$ & $* * *$ \\
\hline $\log$ of income & $\begin{array}{c}-0.033 \\
(0.206)\end{array}$ & & $\begin{array}{c}-0.028 \\
(0.268)\end{array}$ & & $\begin{array}{c}0.293 \\
(0.080)\end{array}$ & $*$ & $\begin{array}{c}0.352 \\
(0.023)\end{array}$ & $* *$ \\
\hline ROA & $\begin{array}{l}-0.045 \\
(0.028)\end{array}$ & $* *$ & $\begin{array}{c}-0.073 \\
(0.000)\end{array}$ & $* * *$ & $\begin{array}{c}-1.209 \\
(0.000)\end{array}$ & $* * *$ & $\begin{array}{c}-1.254 \\
(0.000)\end{array}$ & $* * *$ \\
\hline deposits to liabilities & $\begin{array}{c}0.067 \\
(0.404)\end{array}$ & & $\begin{array}{c}0.027 \\
(0.743)\end{array}$ & & $\begin{array}{l}-0.377 \\
(0.451)\end{array}$ & & $\begin{array}{c}0.323 \\
(0.506)\end{array}$ & \\
\hline equity to assets & $\begin{array}{l}-1.128 \\
(0.052)\end{array}$ & $*$ & $\begin{array}{l}-1.320 \\
(0.180)\end{array}$ & & $\begin{array}{c}-10.598 \\
(0.000)\end{array}$ & $* * *$ & $\begin{array}{r}-13.845 \\
(0.000)\end{array}$ & $* * *$ \\
\hline Country effects & Yes & & Yes & & Yes & & Yes & \\
\hline Year effects & Yes & & Yes & & Yes & & Yes & \\
\hline Number of observations & 607 & & 677 & & 671 & & 751 & \\
\hline
\end{tabular}


Geographic reach and bank risk - earnings volatility

Table 6

Dependent variables is the Excess earnings volatility. Excess values are defined as the difference between the actual risk level of bank ${ }_{j}$ and its adjusted risk: Adjusted Risk $=\alpha_{j}$ Risk $_{1}+\left(1-\alpha_{j}\right)$ Risk $k_{2}$, where Risk $k_{1}$ is the average Risk level of the banks with international diversification levels above the $70 \%$ threshold (i.e., highly diversified multinational commercial banks), and Risk $k_{2}$ represents the average Risk level of the banks equal to or below the $30 \%$ threshold. We computed the excess value of the following risk measure: (i) the earnings volatility, which is computed with a three-year rolling widow. For bank $j, \alpha$ is the index of geographical dispersion in foreign countries, where $\alpha_{j}=n_{j} / n_{\max }, n_{j}$ is the number of foreign countries in which bank $j$ has a subsidiary, and $n_{\max }$ is the maximum number of foreign countries in which the most diversified bank has subsidiaries. Geographic reach is the ratio of $n_{j, t}$ to $n_{\max , t}$, where $n_{j t}$ is the number of foreign countries in which bank $j$ has a subsidiary in year $t$, and $n_{\max , t}$ is the maximum number of foreign countries in which the most diversified bank has subsidiaries in year $t$. The alternative measures of geographic diversification include the following: (i) the subsidiaries concentration, which is proxied by a transformed Hirsch-Herfindhal index (HHI) $\left(1-\sum_{\mathrm{j}}\right.$ (subsidiary $_{j}$ assets/total subsidiaries assets) ${ }^{2}$ ); and (ii) the geographic dispersion of subsidiaries (geographic share), which is estimated by 1 - [(total subsidiaries assets - foreign subsidiaries assets) / (total subsidiaries assets)]. The bank controls include the following: (i) the logarithm of total assets (log assets); (ii) the logarithm of total operating income (log income); (iii) ROA as a proxy for profitability; (iv) access to funding, which is proxied by the ratio of deposits to liabilities; and (v) capitalization which is proxied by equity to assets. Estimation is with robust regression techniques. We included but do not report the country and year fixed effects. We trimmed excess risk at the $5^{\text {th }}$ and $95^{\text {th }}$ percentiles. The p-values are in parentheses. Significance at the $1 \%, 5 \%$, and $10 \%$ levels is denoted by $* * *, * *$, and $*$, respectively.

\section{(1)}

$(0.000)$

geographic reach

HHI

geographic share

$\log$ of assets

$\log$ of income

ROA

deposits to liabilities

equity to assets

Country effects

Year effects

Number of observations
(2)

(3)

\section{Earnings volatility}

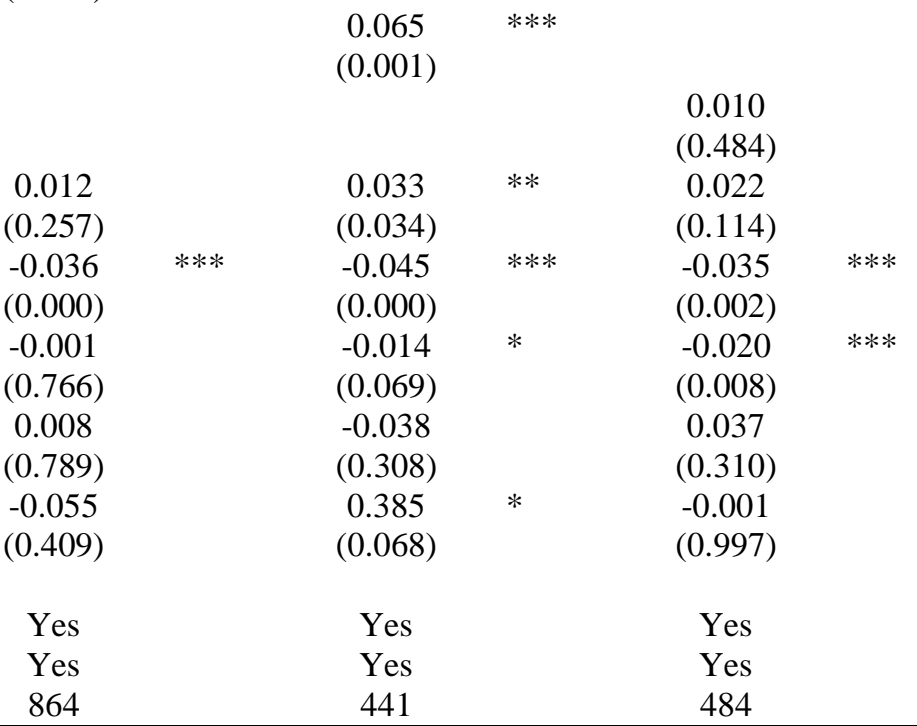


Robustness test of the impact of geographic reach on bank risk: controlling for endogeneity

Dependent variables are Excess EDF and Excess Z'-score. Excess values are defined as the difference between the actual risk level of bank ${ }_{j}$ and its adjusted risk: Adjusted Risk $=\alpha_{j}$ Risk $_{1}+\left(1-\alpha_{j}\right)$ Risk $k_{2}$, where Risk $k_{1}$ is the average Risk level of the banks with international diversification levels above the 70\% threshold (i.e., highly diversified multinational commercial banks), and Risk $k_{2}$ represents the average Risk level of the banks equal to or below the $30 \%$ threshold. We computed the excess values of the following risk measures: (i) the 5-year expected default frequency (EDF), which proxies the likelihood to default; (ii) a transformed Z'score, which is the symmetric value of $(C A R+E Q T) / \sigma(R O A))$ that gauges the proximity to default, where CAR is the capital asset ratio, EQT is the equity-toassets ratio, and $\sigma(\mathrm{ROA})$ is the volatility of assets. For bank $j, \alpha$ is the index of geographical dispersion in foreign countries, where $\alpha_{j}=n_{j} / n_{m a x}, n_{j}$ is the number of foreign countries in which bank $j$ has a subsidiary, and $n_{\max }$ is the maximum number of foreign countries in which the most diversified bank has subsidiaries.

Geographic reach is the ratio of $n_{j, t}$ to $n_{\text {max }, t}$, where $n_{j t}$ is the number of foreign countries in which bank $j$ has a subsidiary in year $t$, and $n_{\text {max }, t}$ is the maximum number of foreign countries in which the most diversified bank has subsidiaries in year $t$. The bank controls include the following: (i) the logarithm of total assets (log assets); (ii) the logarithm of total operating income (log income); (iii) ROA as a proxy for profitability; (iv) access to funding, which is proxied by the ratio of deposits to liabilities; and (v) capitalization which is proxied by equity to assets. We included but do not report the country and year fixed effects. We trimmed excess risk at the $5^{\text {th }}$ and $95^{\text {th }}$ percentiles. The p-values are in parentheses. Significance at the $1 \%, 5 \%$, and $10 \%$ levels is denoted by $* * *, * *$, and $*$, respectively.

\begin{tabular}{|c|c|c|c|c|c|c|c|c|c|c|c|c|}
\hline & \multicolumn{2}{|l|}{ (1) } & \multicolumn{2}{|l|}{ (2) } & \multicolumn{2}{|c|}{ (3) } & \multicolumn{2}{|l|}{ (4) } & \multicolumn{2}{|c|}{$(5)$} & \multicolumn{2}{|l|}{ (6) } \\
\hline & \multicolumn{6}{|c|}{ Excess EDF } & \multicolumn{6}{|c|}{ Excess Z'-score } \\
\hline & \multicolumn{2}{|c|}{ Fixed effects } & \multicolumn{2}{|c|}{ Dynamic GMM } & \multicolumn{2}{|l|}{ IV } & \multicolumn{2}{|c|}{ Fixed effects } & \multicolumn{2}{|c|}{ Dynamic GMM } & \multicolumn{2}{|l|}{ IV } \\
\hline lagged excess EDF & & & $\begin{array}{c}0.681 \\
(0.000)\end{array}$ & $* * *$ & & & & & & & & \\
\hline lagged excess Z'-score & & & & & & & & & $\begin{array}{r}0.877 \\
(0.000)\end{array}$ & $* * *$ & & \\
\hline geographic reach & $\begin{array}{r}0.499 \\
(0.000)\end{array}$ & $* * *$ & $\begin{array}{r}0.241 \\
(0.026)\end{array}$ & $* *$ & $\begin{array}{r}3.261 \\
(0.000)\end{array}$ & $* * *$ & $\begin{array}{r}0.587 \\
(0.000)\end{array}$ & $* * *$ & $\begin{array}{r}0.953 \\
(0.068)\end{array}$ & $*$ & $\begin{array}{r}5.867 \\
(0.000)\end{array}$ & $* * *$ \\
\hline $\log$ of assets & $\begin{array}{r}-0.312 \\
(0.136)\end{array}$ & & $\begin{array}{r}-0.006 \\
(0.843)\end{array}$ & & $\begin{array}{r}0.793 \\
(0.002)\end{array}$ & $* * *$ & $\begin{array}{r}-0.096 \\
(0.068)\end{array}$ & $*$ & $\begin{array}{r}-0.222 \\
(0.048)\end{array}$ & $* *$ & $\begin{array}{r}-1.480 \\
(0.000)\end{array}$ & $* * *$ \\
\hline log of income & $\begin{array}{r}-0.057 \\
(0.347)\end{array}$ & & $\begin{array}{r}-0.020 \\
(0.416)\end{array}$ & & $\begin{array}{r}-0.607 \\
(0.014)\end{array}$ & $* *$ & $\begin{array}{r}-0.045 \\
(0.335)\end{array}$ & & $\begin{array}{r}0.094 \\
(0.333)\end{array}$ & & $\begin{array}{r}0.343 \\
(0.072)\end{array}$ & $*$ \\
\hline ROA & $\begin{array}{r}-0.089 \\
(0.001)\end{array}$ & $* * *$ & $\begin{array}{r}-0.054 \\
(0.000)\end{array}$ & $* * *$ & $\begin{array}{r}-0.739 \\
(0.000)\end{array}$ & $* * *$ & $\begin{array}{r}-0.033 \\
(0.394)\end{array}$ & & $\begin{array}{r}-0.371 \\
(0.000)\end{array}$ & $* * *$ & $\begin{array}{r}-0.673 \\
(0.000)\end{array}$ & $* * *$ \\
\hline deposits to liabilities & $\begin{array}{r}0.282 \\
(0.009)\end{array}$ & $* * *$ & $\begin{array}{r}-0.289 \\
(0.131)\end{array}$ & & $\begin{array}{r}-0.780 \\
(0.002)\end{array}$ & $* * *$ & $\begin{array}{r}-0.033 \\
(0.794)\end{array}$ & & $\begin{array}{r}-0.198 \\
(0.739)\end{array}$ & & $\begin{array}{r}0.474 \\
(0.585)\end{array}$ & \\
\hline equity to assets & $\begin{array}{r}-1.820 \\
(0.216)\end{array}$ & & $\begin{array}{r}0.025 \\
(0.960)\end{array}$ & & $\begin{array}{r}-9.291 \\
(0.010)\end{array}$ & $* * *$ & $\begin{array}{r}-1.520 \\
(0.139)\end{array}$ & & $\begin{array}{r}3.107 \\
(0.100)\end{array}$ & $*$ & $\begin{array}{r}-14.300 \\
(0.000)\end{array}$ & $* * *$ \\
\hline Country effects & Yes & & Yes & & Yes & & Yes & & Yes & & Yes & \\
\hline Year effects & Yes & & Yes & & Yes & & Yes & & Yes & & Yes & \\
\hline Number of observations & 956 & & 757 & & 1,168 & & 583 & & 925 & & 678 & \\
\hline
\end{tabular}

